\title{
Microbial Biomass and Respiration of Soil Cultivated with Wheat Grown on Calcareous Soil as Influenced by Nitrogen Fertilization, Biofertilization and Farmyard Manure Application
}

\author{
I.H. Elsokkary, ${ }^{1}$ A. E. Abd El-All, and H. E. Gomaa ${ }^{2}$
}

\begin{abstract}
The objectives of the present study were to evaluate the influence of mineral $\mathbf{N}$ fertilizer alone or in combination with biofertilizer (B) or farmyard manure (FYM) on the microbial biomass carbon (MBC), microbial biomass nitrogen (MBN) and soil respiration (SR) of soils collected at tillering, heading and harvest growth stages of wheat plant grown on calcareous soil.

Field experiment was carried out at El-Noubariya Res. St., Ministry of Agriculture and Land Reclamation. The experimental design was split plot in four riplicates where $\mathrm{N}$ was the main treatment $(0,30,60$ and $90 \mathrm{kgN} / \mathrm{Fed})$ as ammonium nitrate, and biofertilizer: cerialin (B) or farmyard manure (FYM) was the sub-treatment. Phosphorus as superphosphate fertilizer and potassium as potassium sulfate fertilizer were applied to the soil before seed sowing during tillage practices. The seeds of wheat (Triticum aestivum L.) variety Giza 168 were sown in Dec. 2007.

The obtained results showed significant increases in the levels of MBC, MBN and SR with increasing rates of applied $\mathbf{N}$ alone and in combination with $B$ or with FYM. The levels of $\mathrm{MBC}$ were higher in soils $(0-20 \mathrm{~cm})$ collected at heading growth stage (mean values of 413.7 and $675.3 \mathrm{mgC} / \mathrm{kg}$ soil for $\mathrm{N}+\mathrm{B}$ and for $\mathrm{N}+\mathrm{FYM}$ treatments, respectively) than at tillering and harvest growth stages. The levels of $\mathrm{MBN}$ were higher in soils (0 $20 \mathrm{~cm}$ ) collected at tillering (mean values of 225.3 and $352.1 \mathrm{mg} \mathrm{N} / \mathrm{kg}$ soil with $\mathrm{N}+\mathrm{B}$ and $\mathrm{N}+$ FYM treatments, respectively) than at heading and harvest growth stages. In addition, the levels of $S R$ were higher in soils $(0-20 \mathrm{~cm})$ collected at heading (mean values of 173.4 and $281.4 \mathrm{mg}$ $\mathrm{CO}_{2} / \mathrm{kg}$ soil with $\mathrm{N}+\mathrm{B}$ and $\mathrm{N}+\mathrm{FYM}$ treatments, respectively) than at tillering and harvest growth stages. These data suggest that combined use of organic manure such as FYM with mineral $\mathbf{N}$ fertilizer would maintain high microbial biomass in calcareous soil.
\end{abstract}

Keywords:Microbial biomass carbon, Microbial biomass nitrogen,Soil respiration, Available nitrogen

\section{INTRODUCTION}

Soil biological activity, including mainly microbial biomass, basal respiration, and soil enzymatic activities, has been proved to be closely related to several soil properties such as $\mathrm{pH}$, organic matter, soil water and temperature regimes. These biochemical soil characters can be utilized as indicators for changes in soil quality (Ros et al., 2003; Bending et al., 2004 and Bastida et al., 2008). Soil microbial biomass (SMB) has been found to be a sensitive indicator of agricultural practices, inputs of inorganic and organic fertilizers and crop rotation (Bending et al., 2004).

Organic fertilization usually increases soil microbial biomass (Liang et al., 2003 and Kaur et al., 2005) and soil respiration (Crecchio et al., 2001 and Liang et al, 2003). It is obvious that soil microbial biomass is strongly dependent on soil temperature and moisture content with only small fluctuations (Murphy et al., 2007; Bastida et al., 2008 and Feng and Simpson, 2009). Chen et al. (2003) found that soil respiration (SR) rate was related to soil temperature and moisture, and was higher in summer then in other seasons.

It is obvious that organic manures contain usually large numbers of variable and dead-living microorganisms, huge quantities of readily utilized energy sources and inorganic fertilizers rich in available nutrients. These materials stimulate microorganisms to absorb nutrients and result in higher soil microbial biomass (Ge et al., 2010). The higher microbial biomass values observed in soils might be a consequence of both increased nutrients in soils and nutrients storage by microorganisms due to the presence of organic materials and plant root secretion (Ge et al., 2010).

It has been also reported that soil respiration decreased as soil depth increased. This might be related to a greater amount of organic materials available at the soil surface in addition to the increase in the contents of nutrients which would stimulate microbial activity, thus leading to an increase in soil respiration (Ge et al., 2010).

The objectives of the present study, therefore, were to evaluate the influence of nitrogen fertilization, biofertilization and farm yard manure application on microbial biomass carbon, microbial biomass nitrogen and soil respiration of soil cultivated with wheat grown on calcareous soil.

\footnotetext{
${ }^{1}$ Department of Soil and Water Sciences, Faculty of Agriculture, El Shatby, Alexandria university, Egypt. E-mail: elsokkary35@gmail.com

${ }^{2}$ Soil, Water and Environ. Res. Inst., El-Noubariya,

Ministry of Agriculture and Land Reclamation, Egypt.

Received December 08, 2011, Accepted December31, 2011.
} 


\section{MATERIALS AND METHODS}

Field experiment was carried out, during the winter season of 2007 - 2007 at El Noubariya Research Station, Agri. Res. Center, Ministry of Agriculture and Land Reclamation (MALR). According to the meteorological data of the region (Banger El Sokkar Station), the average minimum temperature during the growth season was $11^{\circ} \mathrm{C}$ and that of the maximum was $33^{\circ} \mathrm{C}$, the quantities of the rainfall, during Dec. 2007, Jan. 2008 and Feb. 2008, were 17, 30 and $8 \mathrm{~mm}$, respectively, the relative humidity varied from 62 to $79 \%$, wind speed ranged from 1.5 to $2.1 \mathrm{~m} / \mathrm{sec}$, and the average evapotranspiration rate was $1.2 \mathrm{~mm} /$ day. The experimental soil is a calcareous: (Typic calciorthids). The main chemical and physical characteristics of the soil are shown in Table 1. The source of irrigation water was El Noubariya canal, and the main chemical properties of this water are shown in Table 2.

\section{Experimental Layout}

The experimental design was split plot in four replicates where nitrogen $(\mathrm{N})$ was the main treatment and biofertilizer (B) or farm yard manure (FYM) was the sub-treatment.

The $\mathrm{N}$ fertilizer (ammonium nitrate, 33.3\% $\mathrm{N}$ ) was applied at rates of $00,30,60$ and $90 \mathrm{~kg}$ N/Fed.. Each rate was divided into three equal doses and applied to the soil at land preparation (before seed sowing), after 20 and 50 days from sowing.

The biofertilizer (serialin) was obtained from Soil Microbiology Unit, Soil, Water Environ. Res. Inst., MALR. The serialin was added to the seeds of wheat as aqueous solution containing gum.

The used farmyard manure (FYM) consisted from composted organic farm residues and wastes produced in the local farms of the region. It was applied to the soil at a rate of $20 \mathrm{~m}^{3} / \mathrm{Fed}$, after plot division and before seed sowing. The main chemical properties of the FYM are shown in Table 3.

Table 1. The main chemical and physical characteristics of the used experimental soil (mean values)

\begin{tabular}{|c|c|c|}
\hline \multirow{2}{*}{ Soil character } & \multicolumn{2}{|c|}{ Soil depth $(\mathrm{cm})$} \\
\hline & 0 - 20 & $20-40$ \\
\hline$E C_{e}, d S / m$ & 1.28 & 1.34 \\
\hline pH & 8.11 & 8.18 \\
\hline Total carbonate $\%$ & 23.0 & 23.3 \\
\hline Available N, mg/kg soil & 41.9 & 35.2 \\
\hline Available $\mathbf{P}, \mathrm{mg} / \mathrm{kg}$ soil & 6.7 & 2.5 \\
\hline Available K, mg/kg soil & 379 & 183 \\
\hline Organic matter $\%$ & 0.70 & 0.32 \\
\hline Soil biomass carbon , mg C/kg soil & 216.2 & 96.0 \\
\hline Soil biomass nitrogen, $\mathrm{mg} \mathrm{N} / \mathrm{kg}$ soil & 109.8 & 50.2 \\
\hline Soil respiration, $\mathrm{mg} \mathrm{CO} / \mathrm{kg}$ soil & 138.3 & 84.6 \\
\hline \multicolumn{3}{|l|}{ Pasticle size distribution: } \\
\hline Sand, \% & $56-9$ & 57.3 \\
\hline Silt, \% & $20-2$ & 21.6 \\
\hline Clay, \% & 22.9 & 21.1 \\
\hline Soil texture & SCL & SCL \\
\hline \multicolumn{3}{|c|}{ Table 2. The main chemical properties of the water of El- Noubaria canal (mean values } \\
\hline EC (ds/m) & \multicolumn{2}{|c|}{1.71} \\
\hline pH & \multicolumn{2}{|c|}{7.2} \\
\hline SAR & \multicolumn{2}{|c|}{6.0} \\
\hline Degree of restriction on use & \multicolumn{2}{|c|}{ Slight to moderate ${ }^{*}$} \\
\hline \multirow{2}{*}{\multicolumn{3}{|c|}{$\begin{array}{l}\text { *Ayers and Westcot (1985). } \\
\text { Table 3. The main chemical characteristics of the farmvard manure (mean values) }\end{array}$}} \\
\hline & & \\
\hline \multicolumn{3}{|l|}{$E C^{*},(d S / m)$} \\
\hline $\mathbf{p H}^{* *}$ & \multicolumn{2}{|c|}{8.78} \\
\hline Organic carbon ,\% & \multicolumn{2}{|c|}{18.24} \\
\hline Total nitrogen ,\% & \multicolumn{2}{|c|}{0.75} \\
\hline Total phvsphorus ,\% & \multicolumn{2}{|c|}{0.15} \\
\hline Total potassium ,\% & \multicolumn{2}{|c|}{1.09} \\
\hline C / N ratio & \multicolumn{2}{|c|}{24.32} \\
\hline
\end{tabular}

*measured in 1:10 FYM- water ratio.

** measured in 1:2.5 FYM- water suspension. 
The seeds of wheat ( $\underline{\text { Triticum }}$ aestivum $\underline{\text { L.) }}$ ) variety Giza 168 were obtained from Wheat Res. Dept., Field Crop Res. Inst., Agric. Res. Center, MARL. And were sown in Dec. 2007.

Phosphorus and potassium fertilizations were carried out as follows: $\mathrm{P}$ was applied as superphosphate fertilizer $\left(12.5 \% \mathrm{P}_{2} \mathrm{P}_{5}\right)$ at a rate of $17 \mathrm{~kg} \mathrm{P}_{2} \mathrm{P}_{5} / \mathrm{Fed}$., and $\mathrm{K}$ was applied as potassium sulfate $\left(48 \% \mathrm{~K}_{2} \mathrm{O}\right)$ at a rate of $24 \mathrm{~kg} \mathrm{~K}{ }_{2} \mathrm{O} / \mathrm{Fed}$. These two fertilizers were applied to the soil before sowing, mixed thoroughly in the upper soil layer $(0-20 \mathrm{~cm})$ during tillage practices.

\section{Soil Sampling}

Composite soil samples were collected from the experimental field before cultivation at two depths $(0-$ 20 and $20-40 \mathrm{~cm}$ ). These soils were air-dried, ground, passed through a $2 \mathrm{~mm}$ sieve and stored for analysis. Also, composite soil samples were collected from each experimental plot at two depths $(0-20$ and $20-40 \mathrm{~cm})$ at three times: (i) 30 days after sowing (tillering growth stage), (ii) 75 days after sowing (heading growth stage) and (iii) 132 days after sowing (harvest growth stage). Each soil sample was devided into two portions: (i) the first was air-dried, ground, passed through a $2 \mathrm{~mm}$ sieve and stored for analysis, and (ii) the second was preserved in an ice-box and immediately analyzed for soil microbial biomass.

\section{Soil Analysis}

The chemical characteristics of the soil were determined as follows: $\mathrm{EC}_{\mathrm{e}}$ was measured in the water extract of saturated soil paste, $\mathrm{pH}$ was measured in 1 : 2.5 soil - water suspension (Black, 1965), the amount of available $\mathrm{N}$ was measured in $1 \mathrm{~N} \mathrm{KCl}$ soil extract by microkjeldahl, and the amount of available $\mathrm{P}$ was measured coloremetrically in soil extract of $0.5 \mathrm{M}$ $\mathrm{NaHCO}_{3}$ of pH 8.5 (Page et al., 1982). The amount of available $\mathrm{K}$ was measured by flame photometer in the soil extract of $\mathrm{N} \mathrm{NH}_{4} \mathrm{OA}_{\mathrm{c}}$ of $\mathrm{pH} 7.0$ and the amount of organic carbon (O.C.) was determined using dichromate oxidation method (Walkley and Black) and the amount of organic matter (O.M.) was obtained by multiplying O.C. with 1.72 (Black, 1965).

The particle size distribution (sand, silt and clay) was determined by the hydrometer method as outlined in Black (1965)

Soil microbial biomass components were determined as follows

i-Microbial biomass carbon (MBC) was determined by the chloroform fumigation method (Andreson, 1982), and soil microbial biomass carbon was calculated according to the method described by Voroney and Pual (1984).
ii-Microbial biomass nitrogen (MBN) was determined by using the chloroform fumigation procedure and the concentration of $\mathrm{N}$ was measured by Kjeldahl (Jackson, 1973) and MBN was calculated according to the method described by Brookes et al. (1985).

iii-Soil respiration (SR) was measured according to the method described by Kaloosh (1978).

\section{Statistical Analysis}

The obtained data were statistically analyzed using the COSTAT software (Cohort, 1986) statistical pakage for the least significant difference (Steel and Torrie, 1984).

\section{RERSULTS AND DISCUSSION}

The soil of El-Noubariya Agricultural Research Station is calcareous (Typic Calciorthids). It contains appreciable amounts of total carbonate (23.0 and $23.3 \%$ in soils of the $0-20$ and $20-40 \mathrm{~cm}$ layers, respectively). The values of $\mathrm{EC}_{\mathrm{e}}$ are relatively low (1.28 and $1.34 \mathrm{dS} / \mathrm{m}$ in the upper and lower soil layers, respectively). The soil is generally characterized by low organic matter content $(0.70$ and $0.32 \%$ in the upper and lower layers, respectively) and low levels of available $\mathrm{N}, \mathrm{P}$ and $\mathrm{K}$ contents and also low levels of MBN, MBC and SR (Table 1). All these characters reveal that this soil has low fertility level.

The following paragraphs represent the results obtained concerning the influence $\mathrm{N}$ fertilizer application alone or incombination with biofertilizer (B) or with farm yard manure (FYM) on the levels of MBC, MBN and SR in soils collected at tillering, heading and harvest growth stages of wheat plant grown on calcareous soil.

\section{Effect of $\mathbf{N}$ Application}

\section{1-Available $\mathbf{N}$ in soil (Av. $\mathbf{N}$ )}

Table 4 showed significant increase in the amounts of available $\mathrm{N}$ with increasing rates of $\mathrm{N}$ applied, in soils collected at tillering, heading and harvest growth stages. It is also clear that the amounts of available $\mathrm{N}$ were almost higher in soils of the upper layer $(0-20$ $\mathrm{cm})$ than in those of the lower layer $(20-40 \mathrm{~cm})$. Ryan et al., (1997), in their studies on wheat fertilization with mineral $\mathrm{N}$, found that the greatest mineral $\mathrm{N}$ concentration had occurred in the topsoil $(0-20 \mathrm{~cm})$ and decreased with soil depth.

The amounts of available $\mathrm{N}$, in soils of the upper layer $(0-20 \mathrm{~cm})$, were higher in soils collected at tillering growth stage (mean value of $44.6 \mathrm{mg} \mathrm{N} / \mathrm{kg}$ soil) than in those at heading (mean value $39.1 \mathrm{mg} \mathrm{N} / \mathrm{kg}$ soil) and in those at harvest (mean value of $33.3 \mathrm{mg} \mathrm{N} / \mathrm{kg}$ soil). The high level exhibited in soil at tillering growth 
stage could be due to both high $\mathrm{N}$ applied (two doses of $\mathrm{N}$ ) at this growth stage and relatively low amount of $\mathrm{N}$ which can be taken up by plant root relative to that applied to the soil. On the other hand, in spite of the cumulative doses of $\mathrm{N}$ applied to the soil (three doses of $\mathrm{N}$ ), the amount of available $\mathrm{N}$ in soils at heading were relatively lower than those at tillering. This indicates high rate of $\mathrm{N}$ absorption by plant root system at heading growth stage as a result of crop vigour and high rhizosphere system. In addition, at harvest growth stage, the loss of $\mathrm{N}$ by volatilization is becoming a reliable process under the conditions of wheat cultivation and hence the amount of available $\mathrm{N}$ in soil has been decreased (Matson et al., 1998 and Laegried et al., 1999). In general, Table 4 showed clearly that the amount of available $\mathrm{N}$ in soils had decreased with proceeding plant age and with soil depth.

Table 5 showed a marked increase in the values of the relative variation in the amounts of available $\mathrm{N}$ with increasing rates of applied $\mathrm{N}$, with both soils of the upper and lower layers. In addition, there is a positive relation between increasing rates of applied $\mathrm{N}$ to the soil, the amounts of available $\mathrm{N}$ in soil, and the values of the relative variation of available $\mathrm{N}$ in soils. It is also clear that the highest values of the relative variation, of the amounts of available $\mathrm{N}$ in soils, were related to the highest rate of applied $\mathrm{N}$ (90 kg N/Fed) and in soils at harvest growth stages for soils of the two layers. This could be due to the low amounts of $\mathrm{N}$ taken up by root under these conditions (harvest growth stage) as compares with those at tillering and heading growth stages.

\section{2-Microbial biomass carbon (MBC)}

Table 4 showed significant increase in the levels of $\mathrm{MBC}$ in soils collected at tillering, heading and harvest growth stages of wheat plant with increasing rates of applied N. Several studies found that the levels of MBC in soils had increased with increasing rates of applied mineral N fertilizers (Lovell and Hatch, 1998; Kaur et al., 2005 and Ge et al., 2010).

It is clear from Table 4 that the levels of MBC were almost higher in soils of the upper layer $(0-20 \mathrm{~cm})$ than in those of the lower layer $(20-40 \mathrm{~cm})$. This may be due to higher intensive proliferation of the root system of wheat plant in the upper soil layer than in the lower soil layer (Russell, 1977) and also to the relatively higher levels of $\mathrm{N}$ in soils of the upper layer than in those of the lower layer (Ryan et al., 1997).

Table 4 also showed that the levels of MBC, in soils of the upper layer, were higher in soils collected at heading (mean value of $319.8 \mathrm{mg} \mathrm{C} / \mathrm{kg}$ soil) than in those collected at tillering (mean value of $244.6 \mathrm{mg}$ $\mathrm{C} / \mathrm{kg}$ soil) and the lower were in soils collected at harvest (mean value of $172.3 \mathrm{mg} \mathrm{C} / \mathrm{kg}$ soil). These data indicate higher microbial activities in the rhizosphere at heading growth stage than at tillering and the lowest were at harvest growth stage.

Table 5 showed marked increase in the values of the relative variation in the levels of MBC in soils with increasing rates of applied $\mathrm{N}$. The highest values of the relative variation were found, in soils of upper layer, with $\mathrm{N}$ rate of $90 \mathrm{~kg} / \mathrm{Fed}$ at both tillering (19.39\%), heading (15.35\%) and harvest (16.23\%) growth stages. These points out to a marked decrease in the microbial activity in soil with proceeding plant age.

\section{3-Microbial biomass nitrogen (MBN)}

Table 4 showed significant increase in the levels of MBN in soils with increasing rates of applied $\mathrm{N}$ for both soils collected at tillering, heading and harvest growth stages. It is also clear that the levels of $\mathrm{MBN}$ were higher in soils of the upper layer $(0-20 \mathrm{~cm})$ than in those of the lower layer $(20-40 \mathrm{~cm})$ which indicates the positive relation between levels of MBN and amounts of available $\mathrm{N}$ in soils (Table 4). The higher levels of MBN were found in surface soils $(0-20 \mathrm{~cm})$ collected at tillering growth stage (mean value of 174.6 $\mathrm{mg} \mathrm{N} / \mathrm{kg}$ soil), the moderate were in soil collected at heading (mean value of $126.3 \mathrm{mg} \mathrm{N} / \mathrm{kg}$ soil) and the lowest in soils collected at harvest (mean value of 82.2 $\mathrm{mg} \mathrm{N} / \mathrm{kg}$ soil). These data are in positive relationship with the amounts of available $\mathrm{N}$ in soils. It has been reported that application of $\mathrm{N}$ significantly increased the levels of MBN in soils (Kaur et al., 2005).

Table 5 showed marked increase in the values of the relative variation of $\mathrm{MBN}$ with increasing rates of applied $\mathrm{N}$ especially in soils of the upper layer $(0-20$ $\mathrm{cm})$. The highest values were recorded for $\mathrm{N}$ treatment of $90 \mathrm{~kg} \mathrm{~N} / \mathrm{Fed}$ for soils collected at tillering, heading and harvest growth stages. These values were positively related to the levels of the amounts of available $\mathrm{N}$ in soils. However, this relation did not agree with respect to the soil of the lower layer $(20-40 \mathrm{~cm})$.

\section{4-Soil respiration (SR)}

Table 4 showed significant increase in the levels of $\mathrm{SR}$ with increasing rates of applied $\mathrm{N}$ in soils collected at the three growth stages. It is clear from the data in Table 4 (for the upper soil layer) that the highest levels of SR (mean value of $161.1 \mathrm{mg} \mathrm{CO} / \mathrm{kg}$ soil) were found in soils collected at heading and the lowest (mean value of $114.4 \mathrm{~m} \mathrm{CO}_{2} / \mathrm{kg}$ soil) were found at harvest and moderate levels (mean value of $138.3 \mathrm{mg} \mathrm{CO} / \mathrm{kg}$ soil) were found in soils collected at tillering growth stage. The same trend was found for soils of the lower layer $(20-40 \mathrm{~cm})$. It is also clear that the levels of SR were almost higher in soils of the upper than in those of the 
Table 4. The levels of available $\mathrm{N}$ ( $\mathrm{mg} / \mathrm{kg}$ soil), $\mathrm{MBC}$ ( $\mathrm{mg} \mathrm{C} / \mathrm{kg}$ soil), $\mathrm{MBN}$ (mg N/hg soil) and SR $(\mathrm{mg} \mathrm{CO} / \mathrm{kg}$ soil) of soil samples $(0-20$ and $20-40 \mathrm{~cm})$ collected at tillering, heading and harvest growth stages of wheat as influenced by $\mathrm{N}$ application

\begin{tabular}{|c|c|c|c|c|c|c|c|c|}
\hline \multirow{2}{*}{$\begin{array}{l}\mathrm{N} \text { applied } \\
\text { Kg/Fed }\end{array}$} & \multicolumn{2}{|c|}{ Available N } & \multicolumn{2}{|c|}{ MBC } & \multicolumn{2}{|c|}{ MBN } & \multicolumn{2}{|c|}{ SR } \\
\hline & $0-20 \mathrm{~cm}$ & $20-40 \mathrm{~cm}$ & $0-20 \mathrm{~cm}$ & $20-40 \mathrm{~cm}$ & $0-20 \mathrm{~cm}$ & $20-40 \mathrm{~cm}$ & $0-20 \mathrm{~cm}$ & $20-40 \mathrm{~cm}$ \\
\hline \multicolumn{9}{|c|}{ Tillering } \\
\hline 0 & 42.0 & 30.1 & 270.3 & 85.0 & 164.4 & 41.9 & 123.5 & 72.6 \\
\hline 30 & 43.5 & 30.5 & 286.5 & 89.3 & 168.2 & 42.6 & 132.9 & 74.4 \\
\hline 60 & 45.9 & 32.6 & 297.7 & 95.8 & 177.1 & 41.6 & 140.8 & 77.7 \\
\hline 90 & 46.9 & 33.4 & 323.8 & 96.8 & 188.8 & 42.9 & 156.0 & 78.3 \\
\hline Mean & 44.6 & 31.6 & 294.6 & 91.7 & 174.6 & 42.3 & 138.3 & 75.8 \\
\hline L.C.D 0.05 & 1.3 & 1.6 & 14.9 & 4.2 & 7.9 & 1.0 & 7.4 & 4.5 \\
\hline \multicolumn{9}{|c|}{ Heading } \\
\hline 0 & 36.9 & 32.6 & 297.8 & 85.1 & 118.5 & 35.5 & 142.6 & 79.2 \\
\hline 30 & 38.1 & 34.6 & 319.2 & 89.1 & 124.2 & 34.6 & 152.7 & 83.3 \\
\hline 60 & 40.2 & 36.0 & 312.7 & 89.3 & 127.5 & 36.5 & 165.7 & 83.8 \\
\hline 90 & 41.1 & 36.3 & 343.5 & 88.9 & 134.0 & 34.5 & 182.2 & 88.7 \\
\hline Mean & 39.1 & 34.3 & 319.8 & 88.1 & 126.3 & 34.2 & 161.1 & 83.7 \\
\hline LSD 0.05 & 1.3 & 1.6 & 13.9 & 2.0 & 5.0 & 1.0 & 7.6 & 4.8 \\
\hline \multicolumn{9}{|c|}{ Harvest } \\
\hline 0 & 30.2 & 27.3 & 160.8 & 91.8 & 74.0 & 44.3 & 102.8 & 43.5 \\
\hline 30 & 31.6 & 28.5 & 167.8 & 91.9 & 79.6 & 44.0 & 113.5 & 45.8 \\
\hline 60 & 33.6 & 30.0 & 173.7 & 92.6 & 86.1 & 46.5 & 113.8 & 46.8 \\
\hline 90 & 35.3 & 32.0 & 186.9 & 96.6 & 88.9 & 47.5 & 127.5 & 48.8 \\
\hline Mean & 33.3 & 29.5 & 172.3 & 93.7 & 82.2 & 45.9 & 114.4 & 46.1 \\
\hline LSD 0.05 & 0.2 & 0.3 & 6.9 & 3.3 & 3.1 & 2.2 & 5.6 & 4.8 \\
\hline
\end{tabular}

Table 5. The values of the relative variation (\%) in the levels of available N, MBC, MBN and SR of soil samples $(0-20$ and $20-40 \mathrm{~cm})$ collected at tillering, heading and harvest growth stages of wheat as influenced by $\mathrm{N}$ application

\begin{tabular}{|c|c|c|c|c|c|c|c|c|}
\hline \multirow{2}{*}{$\begin{array}{c}\text { N applied } \\
\text { Kg/Fed }\end{array}$} & \multicolumn{2}{|c|}{ Available N } & \multicolumn{2}{|c|}{ MBC } & \multicolumn{2}{|c|}{ MBN } & \multicolumn{2}{|c|}{ SR } \\
\hline & $0-20 \mathrm{~cm}$ & $20-40 \mathrm{~cm}$ & $0-20 \mathrm{~cm}$ & $20-40 \mathrm{~cm}$ & $0-20 \mathrm{~cm}$ & $20-40 \mathrm{~cm}$ & $0-20 \mathrm{~cm}$ & $20-40 \mathrm{~cm}$ \\
\hline \multicolumn{9}{|c|}{ Tillering } \\
\hline 30 & 3.57 & 1.33 & 5.99 & 5.06 & 2.31 & 1.67 & 6.71 & 2.48 \\
\hline 60 & 9.29 & 8.31 & 10.14 & 12.71 & 7.73 & -0.72 & 15.24 & 7.03 \\
\hline 90 & 11.67 & 10.96 & 19.79 & 13.88 & 14.84 & 2.39 & 26.32 & 7.85 \\
\hline \multicolumn{9}{|c|}{ Heading } \\
\hline 30 & 3.25 & 6.14 & 7.19 & 4.70 & 4.81 & -2.53 & 7.08 & 5.18 \\
\hline 60 & 8.94 & 10.43 & 5.00 & 4.94 & 7.60 & 2.82 & 16.20 & 5.81 \\
\hline 90 & 11.38 & 11.35 & 15.35 & 4.46 & 13.08 & -2.82 & 27.77 & 12.00 \\
\hline \multicolumn{9}{|c|}{ Harvest } \\
\hline 30 & 4.64 & 4.40 & 4.35 & 0.11 & 7.57 & -0.68 & 10.41 & 5.29 \\
\hline 60 & 11.26 & 9.89 & 8.02 & 0.87 & 13.35 & 4.97 & 10.70 & 5.98 \\
\hline 90 & 16.89 & 17.22 & 16.23 & 5.23 & 20.14 & 7.22 & 24.03 & 12.18 \\
\hline
\end{tabular}

lower layer. It has been reported that SR usually decreases as soil depth increases (Ge et al., 2010). The relatively higher levels of SR at tillering and heading than at harvest could be due to the presence of adequate soil moisture (winter and spring seasons) during the period of wheat plant growth, as compared with that at harvest (early summer). Chen et al. (2003), Murphy et al. (2007) and Feng and Simpson (2009) reported that soil respiration had been increased with adequate soil moisture.

Table 5 showed marked increase in the values of the relative variation of SR with increasing rates of applied $\mathrm{N}$. This can be found in both the soils of the two layers $(0-20$ and $20-40 \mathrm{~cm})$. However, these values were mostly higher in soils of the upper than the lower layer. In addition, the highest values of the relative variation in the levels of SR were related to the highest rate of 
applied $\mathrm{N}$ (90 kg N/Fed). This can suggest that there was a positive relation between the values of SR and the amounts of available $\mathrm{N}$ in soils.

\section{Effect of N - B Application 1-Available $\mathbf{N}$ in soil (Av. $N$ )}

Table 6 showed significant increase in the amounts of available $\mathrm{N}$ in the presence of $\mathrm{B}$ and with increasing rates of applied $\mathrm{N}$ in soils collected at tillering, heading and harvest growth stages and in both soils of the upper $(0-20 \mathrm{~cm})$ and lower $(20-40 \mathrm{~cm})$ layers. The highest levels of available $\mathrm{N}$ in soils of the upper layer were found in soils collected at tillering (mean value of 47.7 $\mathrm{mg} / \mathrm{kg}$ soil)and the lowest at harvest (mean value of 36.6 $\mathrm{mg} / \mathrm{kg}$ soil) while those at heading were moderate (mean value of $42.7 \mathrm{mg} / \mathrm{kg}$ soil). Table 7 showed marked increase in the values of relative variation of the amounts available $\mathrm{N}$ with increasing rates of applied $\mathrm{N}$ in both soils of the upper and lower layers and at tillering, heading and harvest growth stages. The highest values were found in soil treated with $90 \mathrm{~kg} \mathrm{~N} / \mathrm{Fed}$ and the lowest were recorded for soil treated with $30 \mathrm{~kg}$ $\mathrm{N} / \mathrm{Fed}$ at the three growth stages, in soils of both the upper and lower layers.

\section{2-Microbial biomass carbon (MBC)}

Table 6 showed significant increase in the levels of $\mathrm{MBC}$ in the presence of $\mathrm{B}$ and with increasing rates of applied $\mathrm{N}$ in soils collected at the three growth stages of wheat. The levels of MBC were almost higher in soils of the upper layer $(0-20 \mathrm{~cm})$ than in those of the lower layer $(20-40 \mathrm{~cm})$. It is also clear that, in soils of the upper layer, the highest levels of MBC occurred in soils collected at heading growth stage (mean value of 413.7 $\mathrm{mg} \mathrm{C} / \mathrm{kg}$ soil) and the lowest in those collected at harvest growth stage (mean value of $226.5 \mathrm{mg} \mathrm{C} / \mathrm{kg}$ soil) while in those collected at tillering were moderate (mean value of $382.6 \mathrm{mg} \mathrm{C} / \mathrm{kg}$ soil). This trend can be observed for soils of the lower layer, Table 7 showed that the values of the relative variation in the levels of MBC were increased with increasing rates of applied $\mathrm{N}$ in the presence of $\mathrm{B}$. The highest values were found in soils $(0-20 \mathrm{~cm})$ treated with $90 \mathrm{~kg} \mathrm{~N} / \mathrm{Fed}$, in the presence of $\mathrm{B}$, and the lowest in soils treated with $30 \mathrm{~kg}$ $\mathrm{N} / \mathrm{Fed}$, in soils collected at the three growth stages of wheat plant. This can be also noticed, to some extent, in soils of the lower layer.

\section{3-Microbial biomass nitrogen (MBN)}

Table 6 showed significant increase in the levels of MBN with increasing rates of applied $\mathrm{N}$ in the presence of B in soils of the two layers $(0-20$ and $20-40 \mathrm{~cm})$. The highest levels of MBN are found in soils $(0-20$ $\mathrm{cm}$ ) collected at tillering (mean value of $225.3 \mathrm{mg} \mathrm{N} / \mathrm{kg}$ soil) and the lowest at harvest (mean value of $92.1 \mathrm{mg}$
$\mathrm{N} / \mathrm{kg}$ soil) while soils collected at heading represented moderate levels (mean value of $164.2 \mathrm{mg} \mathrm{N} / \mathrm{kg}$ soil). The levels of MBN behaved similarly in the lower soil layer $(20-40 \mathrm{~cm})$ as well as in the upper soil $(0-20$ $\mathrm{cm})$. Table 7 showed increasing the values of the relative variation for MBN in soils of the upper layer $(0$ $-20 \mathrm{~cm}$ ) with increasing rates of applied $\mathrm{N}$ in the presence of $\mathrm{B}$. The highest values were found in soils treated with $90 \mathrm{~kg} \mathrm{~N} / \mathrm{Fed}$ and the lowest in soils treated with $30 \mathrm{~kg} \mathrm{~N} / \mathrm{kg}$ soil at the three growth stages. These data point out to the positive relation between rate of applied $\mathrm{N}$ and the levels of MBN in soils especially at early stage of plan.

Table 7 also showed that the value of the relative variation in the levels of SR had been increased with increasing rates of applied $\mathrm{N}$ in the presence of $\mathrm{B}$. The highest values were found in soils of the upper layer with $90 \mathrm{~kg} \mathrm{~N} / \mathrm{Fed}$ treatment in soils collected at heading and the lowest was found at harvest while the moderate was found at tillering growth stage of wheat plant.

\section{Effect of N - FYM Application}

\section{1-Available $\mathbf{N}$ in soil (Av. $N$ )}

Table 8 showed significant increase in the amounts of available $\mathrm{N}$ with increasing rates of applied $\mathrm{N}$ in the presence of farmyard manure (FYM) in soils of the upper and lower layers collected at the three growth stages. It is clear that the amounts of available $\mathrm{N}$ were almost higher in soils of the upper $(0-20 \mathrm{~cm})$ than the lower $(20-40 \mathrm{~cm})$ layer. Also, the amounts of available $\mathrm{N}$ were higher in soils $(0-20 \mathrm{~cm})$ collected at tillering growth stage (mean value of $65.0 \mathrm{mg} / \mathrm{kg}$ soil) than in those collected at heading (mean value of $48.1 \mathrm{mg} / \mathrm{kg}$ soil) and in those collected at harvest (mean value of $39.4 \mathrm{mg} / \mathrm{kg}$ soil).

Table 9 showed increasing values of the relative variation in the amounts of available $\mathrm{N}$ in soils of both the two layers with increasing rates of applied $\mathrm{N}$ in the presence of FYM. The highest values were found in soils treated with $90 \mathrm{~kg} \mathrm{~N} / \mathrm{Fed}$ and the lowest were found in soil treated with $30 \mathrm{~kg} \mathrm{~N} / \mathrm{Fed}$ for both soils of the upper and lower layers.

\section{2-Microbial biomass carbon (MBC)}

Table 8 showed significant increase in the levels of MBC with increasing rates of applied $\mathrm{N}$ in the presence of FYM in soils $(0-20 \mathrm{~cm})$ collected at the three growth stages. These levels were higher in soils of the upper than the lower layer. The highest levels of MBC were observe in soils collected at heading growth stage (mean value of $675.3 \mathrm{mg} \mathrm{C} / \mathrm{kg}$ soil) and the lowest were in those collected at harvest (mean value of $359.9 \mathrm{mg}$ $\mathrm{C} / \mathrm{kg}$ soil) while those collected at tillering (mean value of $607.3 \mathrm{mg} \mathrm{C} / \mathrm{kg}$ soil) ranked in the moderate level. It is 
clear also that there were no significant effects due to rates of applied $\mathrm{N}$ on the levels of MBC in soils of the lower layer as compared with those of the upper layer. Also, Table 9 indicated an increase in the values of the relative variation in the levels of MBC in soils with increasing rates of applied $\mathrm{N}$ in the presence of FYM.

\section{3-Microbial biomass nitrogen (MBN)}

Table 8 showed significant increase in the levels of MBN with increasing rate of applied $\mathrm{N}$ in the presence of FYM in soils of the upper layer $(0-20 \mathrm{~cm})$. These values were higher in soils collected at tillering growth stage (mean value of $352.1 \mathrm{mg} \mathrm{N} / \mathrm{kg}$ soil), then at heading (mean value of $292.2 \mathrm{mg} \mathrm{N} / \mathrm{kg}$ soil)) and at harvest (mean value of $160.2 \mathrm{mg} \mathrm{N} / \mathrm{kg}$ soil). However, there were no significant effects due to $\mathrm{N}$ treatment in the presence of FYM on the level of MBN in soils of the lower layer $(20-40 \mathrm{~cm})$ at the three growth stages of wheat. Table 9 showed marked increase in the values of the relative variation in the level of $\mathrm{MBN}$ with increasing rates of applied $\mathrm{N}$ in the presence of FYM at the three growth stages of wheat plant. The highest

Table 6.The levels of available $\mathrm{N}$ ( $\mathrm{mg} / \mathrm{kg}$ soil), $\mathrm{MBC}$ ( $\mathrm{mg} \mathrm{C} / \mathrm{kg}$ soil), $\mathrm{MBN}$ ( $\mathrm{mg} \mathrm{N} / \mathrm{kg}$ soil) and $\mathrm{SR}(\mathrm{mg} \mathrm{CO} / \mathrm{kg}$ soil) in soil samples $(0-20$ and $20-40 \mathrm{~cm})$ collected at tillering, heating and harvest growth stages of wheat as influenced by $\mathrm{N}$ and biofertilizer (B) treatments

\begin{tabular}{|c|c|c|c|c|c|c|c|c|c|}
\hline \multicolumn{2}{|c|}{ Treatments } & \multicolumn{2}{|c|}{ Av. N } & \multicolumn{2}{|c|}{ MBC } & \multicolumn{2}{|c|}{ MBN } & \multicolumn{2}{|c|}{ SR } \\
\hline $\mathrm{N}, \mathrm{kg} / \mathrm{Fed}$ & B & $0-20 \mathrm{~cm}$ & $20-40 \mathrm{~cm}$ & $0-20 \mathrm{~cm}$ & $\begin{array}{c}20- \\
40 \mathrm{~cm}\end{array}$ & $0-20 \mathrm{~cm}$ & $\begin{array}{c}20- \\
40 \mathrm{~cm}\end{array}$ & $0-20 \mathrm{~cm}$ & $\begin{array}{c}20- \\
40 \mathrm{~cm}\end{array}$ \\
\hline \multicolumn{10}{|c|}{ Tillering } \\
\hline $\mathbf{0}$ & B & 42.5 & 30.0 & 359.6 & 76.6 & 213.7 & 43.9 & 132.8 & 75.9 \\
\hline 30 & B & 44.1 & 31.5 & 363.6 & 84.6 & 218.0 & 43.5 & 139.2 & 71.7 \\
\hline 60 & B & 46.5 & 32.9 & 389.3 & 88.2 & 225.1 & 46.7 & 149.3 & 74.7 \\
\hline 90 & B & 47.7 & 34.0 & 417.8 & 89.8 & 244.3 & 42.8 & 165.4 & 89.7 \\
\hline Mean & & 45.2 & 32.3 & 382.6 & 84.8 & 225.3 & 44.2 & 146.7 & 78.0 \\
\hline LSD 0.05 & & 1.3 & 3.2 & 14.9 & 4.2 & 7.9 & 1.9 & 7.4 & 4.5 \\
\hline \multicolumn{10}{|c|}{ Heading } \\
\hline $\mathbf{0}$ & B & 38.1 & 32.5 & 387.2 & 93.9 & 154.2 & 36.6 & 155.3 & 81.1 \\
\hline 30 & B & 39.2 & 34.2 & 397.2 & 91.4 & 158.9 & 35.6 & 165.5 & 78.0 \\
\hline 60 & B & 41.2 & 35.5 & 413.7 & 93.2 & 165.5 & 36.2 & 177.0 & 76.9 \\
\hline 90 & B & 42.7 & 36.2 & 456.9 & 100.3 & 178.2 & 39.0 & 195.7 & 94.8 \\
\hline Mean & & 40.3 & 34.6 & 413.7 & 94.7 & 164.2 & 36.8 & 173.4 & 82.7 \\
\hline LSD 0.05 & & 1.3 & 3.0 & 14.0 & 3.6 & 5.1 & 1.4 & 7.6 & 4.8 \\
\hline \multicolumn{10}{|c|}{ Harvest } \\
\hline $\mathbf{0}$ & B & 31.2 & 37.7 & 212.5 & 97.0 & 85.0 & 39.3 & 112.7 & 44.6 \\
\hline 30 & B & 42.4 & 28.9 & 222.2 & 101.4 & 88.1 & 39.7 & 122.1 & 42.9 \\
\hline 60 & B & 35.1 & 30.2 & 224.7 & 95.7 & 95.6 & 42.6 & 120.5 & 42.3 \\
\hline 90 & B & 36.6 & 32.4 & 246.7 & 105.0 & 99.7 & 45.7 & 134.6 & 52.2 \\
\hline Mean & & 33.8 & 29.8 & 226.5 & 99.8 & 92.1 & 41.8 & 122.5 & 45.5 \\
\hline LSD 0.05 & & 0.2 & 0.3 & 6.9 & 3.3 & 3.1 & 2.2 & 5.6 & 2.7 \\
\hline
\end{tabular}

values of relative variation were found in soils treated with $90 \mathrm{~kg} \mathrm{~N} / \mathrm{Fed}$ and the lowest with $30 \mathrm{~kg} \mathrm{~N} / \mathrm{Fed}$. These were lower at tillering than at heading and harvest growth stages of wheat plants.

\section{4-Soil respiration (SR)}

Table 8 indicated significant increase in the levels of $\mathrm{SR}$, especially in the upper soil layer, with increasing rates of applied $\mathrm{N}$ in the presence of FYM, in soils collected at the three growth stages. The highest levels of SR were found in soils collected at heading growth stage (mean value of $281.4 \mathrm{mg} \mathrm{CO} / \mathrm{kg}$ soil) and the lowest levels were at harvest growth stage (mean value of $204.5 \mathrm{mg} \mathrm{CO} / \mathrm{kg}$ soil) while the levels of SR at tillering growth stage (mean value of $281.4 \mathrm{mg} \mathrm{CO}_{2} / \mathrm{kg}$ soil) were moderate. Table 9 showed marked increase in the values of the relative variation of SR with increasing rates of applied $\mathrm{N}$ in the presence of FYM. The highest values of relative variation were found in soils treated with $90 \mathrm{~kg} \mathrm{~N} / \mathrm{Fed}$ at the three growth stages and the lowest were found in soils treated with $30 \mathrm{~kg} \mathrm{~N} / \mathrm{Fed}$. 
Table 7. The values of the relative variation (\%) in the levels of available N, MBC, MBN and SR of soil samples $(0-20$ and $20-40 \mathrm{~cm})$ collected at tillering, heading and harvest growth stages of wheat as influenced by $\mathrm{N}$ and biofertilizer (B) treatments

\begin{tabular}{|c|c|c|c|c|c|c|c|c|c|}
\hline \multicolumn{2}{|c|}{ Treatments } & \multicolumn{2}{|c|}{ Av. $\mathbf{N}$} & \multicolumn{2}{|c|}{ MBC } & \multicolumn{2}{|c|}{ MBN } & \multicolumn{2}{|c|}{ SR } \\
\hline $\mathrm{N}, \mathrm{kg} / \mathrm{Fed}$ & B & $0-20 \mathrm{~cm}$ & $20-40 \mathrm{~cm}$ & $0-20 \mathrm{~cm}$ & $20-40 \mathrm{~cm}$ & $0-20 \mathrm{~cm}$ & $20-40 \mathrm{~cm}$ & $0-20 \mathrm{~cm}$ & $20-40 \mathrm{~cm}$ \\
\hline \multicolumn{10}{|c|}{ Tillering } \\
\hline 30 & $\mathrm{~B}$ & 3.77 & 1.94 & 1.11 & 10.44 & 2.01 & -0.9 & 4.82 & -5.53 \\
\hline 60 & $\mathrm{~B}$ & 9.41 & 6.47 & 8.26 & 15.14 & 5.34 & 6.38 & 12.43 & -1.58 \\
\hline 90 & B & 12.24 & 10.03 & 16.18 & 17.23 & 14.32 & -2.51 & 24.55 & 18.18 \\
\hline \multicolumn{10}{|c|}{ Heading } \\
\hline 30 & $\mathrm{~B}$ & 2.89 & 5.23 & 2.58 & -2.66 & 3.05 & -2.73 & 6.57 & -3.82 \\
\hline 60 & $\mathrm{~B}$ & 8.14 & 9.23 & 6.84 & -0.76 & 7.33 & -1.09 & 13.97 & -5.18 \\
\hline 90 & $\mathrm{~B}$ & 12.07 & 11.39 & 18.00 & 6.82 & 15.56 & 6.56 & 26.01 & 16.89 \\
\hline \multicolumn{10}{|c|}{ Harvest } \\
\hline 30 & $\mathrm{~B}$ & 3.85 & 4.33 & 4.56 & 4.54 & 3.65 & 1.02 & 8.34 & -3.81 \\
\hline 60 & $\mathrm{~B}$ & 12.50 & 9.03 & 5.74 & -1.34 & 12.47 & 8.40 & 6.92 & -5.16 \\
\hline 90 & $\mathrm{~B}$ & 17.31 & 16.97 & 16.09 & 8.25 & 17.29 & 16.28 & 19.43 & 17.04 \\
\hline
\end{tabular}

Table 8.The levels of available $\mathrm{N}$ ( $\mathrm{mg} / \mathrm{kg}$ soil), $\mathrm{MBC}$ ( $\mathrm{mg} \mathrm{C} / \mathrm{kg}$ soil), $\mathrm{MBN}$ ( $\mathrm{mg} \mathrm{N} / \mathrm{kg}$ soil) and $\mathrm{SR}(\mathrm{mg} \mathrm{CO} / \mathrm{kg}$ soil) in soil samples $(0-20$ and $20-40 \mathrm{~cm})$ collected at tillering, heating and harvest growth stages of wheat as influenced by N and FYM treatments

\begin{tabular}{|c|c|c|c|c|c|c|c|c|c|}
\hline \multicolumn{2}{|c|}{ Treatments } & \multicolumn{2}{|c|}{ Av. N } & \multicolumn{2}{|c|}{ MBC } & \multicolumn{2}{|c|}{ MBN } & \multicolumn{2}{|c|}{ SR } \\
\hline N, kg/ Fed & FYM & $0-20 \mathrm{~cm}$ & $20-40 \mathrm{~cm}$ & $0-20 \mathrm{~cm}$ & $20-40 \mathrm{~cm}$ & $0-20 \mathrm{~cm}$ & $20-40 \mathrm{~cm}$ & $0-20 \mathrm{~cm}$ & $20-40 \mathrm{~cm}$ \\
\hline \multicolumn{10}{|c|}{ Tillering } \\
\hline 0 & FYM & 50.2 & 35.0 & 566.4 & 89.0 & 330.5 & 42.3 & 216.0 & 76.4 \\
\hline 30 & FYM & 53.8 & 36.4 & 575.3 & 91.6 & 338.8 & 45.4 & 221.8 & 87.3 \\
\hline 60 & FYM & 57.9 & 39.3 & 630.1 & 94.7 & 367.6 & 42.6 & 231.3 & 83.4 \\
\hline 90 & FYM & 61.1 & 39.8 & 658.3 & 97.8 & 371.6 & 45.8 & 249.0 & 80.9 \\
\hline Mean & & 56.0 & 37.6 & 607.5 & 93.3 & 352.1 & 44.0 & 259.0 & 82.0 \\
\hline LSD 0.05 & & 1.9 & 3.4 & 25.0 & N.S. & 18.2 & N.S. & 8.4 & N.S. \\
\hline \multicolumn{10}{|c|}{ Heading } \\
\hline 0 & FYM & 43.0 & 37.5 & 601.3 & 90.2 & 239.1 & 34.9 & 261.4 & 88.6 \\
\hline 30 & FYM & 45.9 & 39.6 & 646.6 & 91.0 & 270.3 & 37.5 & 275.8 & 95.4 \\
\hline 60 & FYM & 49.9 & 40.9 & 699.8 & 98.0 & 299.2 & 35.1 & 286.5 & 90.8 \\
\hline 90 & FYM & 53.6 & 43.6 & 753.7 & 97.1 & 292.2 & 37.9 & 302.1 & 80.9 \\
\hline Mean & & 48.1 & 40.4 & 675.3 & 94.1 & 275.2 & 36.9 & 281.4 & 88.4 \\
\hline LSD 0.05 & & 1.5 & 2.8 & 30.3 & N.S. & 23.1 & N.S. & 8.9 & N.S. \\
\hline \multicolumn{10}{|c|}{ Harvest } \\
\hline 0 & FYM & 34.5 & 31.3 & 324.7 & 98.8 & 143.3 & 34.6 & 178.5 & 86.4 \\
\hline 30 & FYM & 38.2 & 34.3 & 349.1 & 106.2 & 157.0 & 48.1 & 188.1 & 95.1 \\
\hline 60 & FYM & 40.8 & 37.8 & 366.5 & 104.1 & 163.9 & 46.6 & 195.4 & 90.7 \\
\hline 90 & FYM & 44.0 & 39.9 & 399.1 & 113.3 & 176.5 & 51.8 & 255.8 & 80.7 \\
\hline Mean & & 39.4 & 35.8 & 359.9 & 105.6 & 160.2 & 47.5 & 204.5 & 88.2 \\
\hline LSD 0.05 & & 2.1 & 3.7 & 12.4 & N.S. & 10.3 & N.S. & 9.2 & N.S. \\
\hline
\end{tabular}


Table 9. The values of the relative variation (\%) in the levels of available N, MBC, MBN and SR of soil samples $(0-20$ and $20-40 \mathrm{~cm})$ collected at tillering, heading and harvest growth stages of wheat as influenced by $\mathrm{N}$ and FYM treatments



\begin{tabular}{|c|c|c|c|c|c|c|c|c|c|}
\hline N, kg/ Fed & FYM & $0-20 \mathrm{~cm}$ & $20-40 \mathrm{~cm}$ & $0-20 \mathrm{~cm}$ & $20-40 \mathrm{~cm}$ & $0-20 \mathrm{~cm}$ & $20-40 \mathrm{~cm}$ & $0-20 \mathrm{~cm}$ & $20-40 \mathrm{~cm}$ \\
\hline \multicolumn{10}{|c|}{ Tillering } \\
\hline 30 & FYM & 7.17 & 4.00 & 1.57 & 2.92 & 2.51 & 7.33 & 2.69 & 14.27 \\
\hline 60 & FYM & 15.34 & 12.29 & 11.25 & 6.41 & 11.23 & 0.71 & 7.08 & 9.16 \\
\hline 90 & FYM & 21.73 & 13.71 & 16.23 & 9.89 & 12.44 & 8.27 & 15.28 & 5.89 \\
\hline \multicolumn{10}{|c|}{ Heading } \\
\hline 30 & FYM & 6.74 & 5.60 & 7.53 & 0.89 & 13.05 & 7.45 & 5.51 & 7.68 \\
\hline 60 & FYM & 16.05 & 9.07 & 16.38 & 8.65 & 25.14 & 0.57 & 9.60 & 2.48 \\
\hline 90 & FYM & 24.65 & 16.27 & 25.35 & 7.65 & 22.21 & 8.60 & 15.57 & -8.69 \\
\hline \multicolumn{10}{|c|}{ Harvest } \\
\hline 30 & FYM & 10.72 & 9.59 & 7.52 & 7.49 & 9.56 & 39.02 & 5.38 & 10.07 \\
\hline 60 & FYM & 18.26 & 20.77 & 12.17 & 5.36 & 14.38 & 34.68 & 9.47 & 4.98 \\
\hline 90 & FYM & 27.54 & 27.48 & 22.91 & 14.68 & 23.17 & 49.71 & 43.31 & -6.60 \\
\hline
\end{tabular}

\section{CONCLUSION}

Tables 4, 6, 8 and 10 showed significant increase in the amount of available $\mathrm{N}$ in soils of the upper layer $(0-$ $20 \mathrm{~cm}$ ) as a result of application of $\mathrm{N}$ miniral fertilizer. Treating the wheat seeds by serialine as biofertilizer (B) had increase the levels of available $\mathrm{N}$ in soils by values of relative increase of $1.35,3.07$ and $1.5 \%$ in soils at tillering, heading and harvest growth stages, respectively relative to $\mathrm{N}$ treatment alone. Soil application of farmyard manure (FYM) in combination with $\mathrm{N}$ increased the amount of available $\mathrm{N}$ in soil relative to fertilization by $\mathrm{N}$ alone since the values of the relative variation in the amount of available $\mathrm{N}$ in soils with $\mathrm{N}+$ FYM treatment were 25.56, 23.02 and $18.3 \%$ in soils at tillering, heading and harvest growth stages, respectively.

It is clear from these data that the presence of B in combination with $\mathrm{N}$ fertilization had little effect on the levels of the amount of available $\mathrm{N}$ in soils. Abd El-All (2010) found that there was no significant interaction effect between rates of applied $\mathrm{N}$ and $\mathrm{B}$ treatment on the amount of available $\mathrm{N}$ in soil. On the other hand, the data presented in Table 10 showed that FYM treatment had significantly increased the levels of available $\mathrm{N}$ in soil as compared with that of B treatment. Abd El-All (2010) reported that there was significant positive effect between rates of applied $\mathrm{N}$ and FYM treatment on the amounts of available $\mathrm{N}$ in soils.

Tables 4, 6, 8 and 10 showed an increase in levels of MBC due to B or FYM treatment with application of $\mathrm{N}$ fertilizer. The values of the relative variation in the levels of MBC due to B treatment were $29.87,29.36$ and $31.46 \%$ in soils at tillering, heading and harvest growth stages, respectively. It has been reported Abd ElAll (2010 that there was a positive significant interaction effect between rates of applied $\mathrm{N}$ and $\mathrm{B}$ treatment. Table
10 showed marked increase in the levels of MBC as a result of FYM treatment with $\mathrm{N}$ fertilization. The values of the relative variation, therefore, due to FYM treatment on the levels of MBC were 106.21, 111.16 and $108.88 \%$ in soils at tillering, heading and harvest growth stages, respectively. These data (Table 10) reveal higher stimulating effect of FYM on improving MBC in soil as compared to that of B treatment. Abd ElAll (2010) found a positive significant interaction effect between rates of applied N and FYM treatment on MBC in soils. Comparing the effect of B and FYM treatment on MBC indicated that FYM was more effective than B. It has been also reported that mineral $\mathrm{N}$ fertilizer application with FYM treatment was responsible for increasing the levels of MBC in soils (Liang et al., 2003; Kaur et al., 2005 and Banergee et al., 2006)

Tables 4, 6, 8 and 10 showed that $\mathrm{N}$ application in combination with B treatment had increased MBN in soil. The values of the relative variation of the level of MBN due to $\mathrm{B}$ treatment, in the presence of $\mathrm{N}$ fertilization, were $29.04,30.00$ and $10.04 \%$ in soils at tillering, heading and harvest, respectively. It has been reported that there was a positive significant interaction effect between rates of applied $\mathrm{N}$ and $\mathrm{B}$ treatment on the level of MBN in soil (Abd El-All, 2010). In the case of $\mathrm{N}+\mathrm{FYM}$ treatment, the values of the relative variation in the levels of MBN were 101.66, 117.89 and $94.89 \%$ in soil at tillering, heading and harvest growth stages, respectively. It has been found that there was a positive significant interaction effect between $\mathrm{N}$ fertilization and FYM treatment on the level of MBN in soil (Abd El-All, 2010). Kaur et al. (2005) found that $\mathrm{N}$ fertilization in combination with FYM treatment had significantly increased MBN in soil. It is clear from these data that FYM treatment was more effective in increasing the level of MBN in soil relative to that of B treatment. 
Tables 4, 6, 8 and 10 indicated an increase in the levels of SR as a result of $\mathrm{N}$ application with B or FYM treatment. The values of the relative variation in the levels of SR, due to B treatment in combination with $\mathrm{N}$ application, were $6.07,7.65$ and $7.08 \%$ in soil at tillering, heading and harvest growth the stages, respectively. Abd El-All (2010) showed a significant positive interaction effect between $\mathrm{N}$ fertilization and $\mathrm{B}$ treatment on the levels of SR in soils $(0-20 \mathrm{~cm})$ at the three growth stages of wheat.

The values of the relative variation in the levels of $\mathrm{SR}$ as a result of FYM treatment in combination with $\mathrm{N}$ fertilization were $87.27,74.67$ and $78.76 \%$ in soils at tillering, heading and harvest growth stages, respectively. The positive significant interaction effect between FYM treatment and $\mathrm{N}$ fertilizer aaplication of wheat plant has been reported by Abd El-All (2010). It has been reported that the use of organic fertilizers usually increase the levels of SR (Crecchio et al., 2001, and Liang et al., 2003). The data shown in Tables 4, 6, 8 and 10 generally indicated that FYM in combination with $\mathrm{N}$ treatment was more effective in increasing $\mathrm{SR}$ as compared to that of $\mathrm{B}$ in combination with $\mathrm{N}$ treatment.

In order to evaluate the effect of $\mathrm{N}$ fertilizer application in combination with B or FYM, the MBC/ MBN ratio was calculated (Table 11). It is clear that this ratio markedly varied according to the growth stage of wheat plant. It was lower in soil collected at tillering than at heading while that in soil collected at harvest was moderate, with all the treatments: $\mathrm{N}, \mathrm{N}+\mathrm{B}$ and $\mathrm{N}+$ FYM., in soils of the upper layer $(0-20 \mathrm{~cm})$. The data in Table 11 showed very close values of $\mathrm{MBC} / \mathrm{MBN}$ ratio for soils collected at tillering and heading with the three treatments $(\mathrm{N}, \mathrm{N}+\mathrm{B}$ or $\mathrm{N}+\mathrm{FYM})$ which indicate that these changes were influenced by season of plant growth rather than fertilization treatments. Ge et al. (2010) found that MBC/ MBN ratio had no significant variation between treatments, but significant differences were observed due to growth season.

It can be concluded that combined use of organic manure such as farm yard manure (FYM) with mineral nitrogen fertilizer would maintain high microbial biomass and respiration in calcareous soil.

Table 10. The mean values of the amounts of available $\mathrm{N}(\mathrm{mg} \mathrm{N} / \mathrm{kg}$ soil), $\mathrm{MBC}(\mathrm{mg} \mathrm{C} / \mathrm{kg}$ soil), MBN (mg N/kg soil) and SR ( $\mathrm{mg} \mathrm{CO} / \mathrm{kg}$ soil) in soils of the upper layer $(0-20 \mathrm{~cm})$ as influenced by N,B and FYM treatments at tillering, heading and harvest growth stages of wheat

\begin{tabular}{llccccccccccc}
\hline \multirow{2}{*}{$\begin{array}{l}\text { Growth } \\
\text { stage }\end{array}$} & \multicolumn{3}{c}{ Available N } & \multicolumn{3}{c}{ MBC } & \multicolumn{3}{c}{ MBN } & \multicolumn{2}{c}{ SR } \\
\hline N & N+B & N+FYM & N & N+B & N+FYM & N & N+B & N+FYM & N & N+B & N+FYM \\
\hline Heading & 44.6 & 45.2 & 56.0 & 294.6 & 382.6 & 607.5 & 174.6 & 225.3 & 352.1 & 138.3 & 146.7 & 259.0 \\
\hline Harvest & 33.1 & 40.3 & 48.1 & 319.8 & 413.7 & 675.3 & 126.3 & 164.2 & 275.2 & 161.1 & 173.4 & 281.4 \\
\hline
\end{tabular}

Table 11. The values of $\mathrm{MBC} / \mathrm{MBN}$ ratio of soils of the upper layer $(0-20 \mathrm{~m})$ as influenced by fertilization treatments and the growth stages of wheat

\begin{tabular}{|c|c|c|c|}
\hline \multirow{2}{*}{ Kg N/ Fed } & \multicolumn{3}{|c|}{ Treatment } \\
\hline & $\mathbf{N}$ & $\mathbf{N}+\mathbf{B}$ & $\mathbf{N}+\mathbf{F Y M}$ \\
\hline & \multicolumn{3}{|c|}{ Tillering } \\
\hline 0 & 1.65 & 1.69 & 1.72 \\
\hline 30 & 1.70 & 1.67 & 1.70 \\
\hline 60 & 1.68 & 1.73 & 1.72 \\
\hline 90 & 1.71 & 1.71 & 1.77 \\
\hline (Mean) & $(1.69)$ & $(1.70)$ & $(1.73)$ \\
\hline \multicolumn{4}{|c|}{ Heading } \\
\hline 0 & 2.52 & 2.51 & 2.52 \\
\hline 30 & 2.57 & 2.51 & 2.39 \\
\hline 60 & 2.47 & 2.50 & 2.34 \\
\hline 90 & 2.56 & 2.56 & 2.58 \\
\hline (Mean) & (2.53) & $(2.52)$ & $(2.46)$ \\
\hline \multicolumn{4}{|c|}{ Harvest } \\
\hline 0 & 2.16 & 2.49 & 2.27 \\
\hline 30 & 2.11 & 2.52 & 2.22 \\
\hline 60 & 2.02 & 2.43 & 2.25 \\
\hline 90 & 2.11 & 2.34 & 2.27 \\
\hline (Mean) & $(2.10)$ & $(2.45)$ & $(2.25)$ \\
\hline
\end{tabular}




\section{REFERENCES}

Abd El-All (2010) Response of wheat plant grown in calcareous soil to nitrogen, biological and organic fertilization under different irrigation conditions. Ph. D. Thesis, Faculty of Agriculture. Alexandria University.

Anderson, J.P.E. (1982) Soil Respiration. In: Methods of soil Analysis. Part 2: Chemical and Microbiological Properties. Page et al., Am. Soc. Agron., Madison. Wisconsin. USA.

Ayers, R. S. and Westcot, D.W. (1985) Water quality for agriculture. FAO Irrigation and Drainage Paper 29 Rev. 1. FAO, Rome.

Banerjee, B., Aggarwal, P.K., Pathak, H., Singh, A. K., and Chaudhary, A. (2006) Dynamics of organic carbon and microbial biomass in alluvial soil with tillage and amendments in rice-wheat system. Environ. Monitoring Assessment. 199: 173 - 189.

Bastida, F., Zsolnay, A., Hernandez, T. and Garcia, C. (2008) Past, Present and future of soil quality indices: a biological prespective. Geoderma. 147: 159 - 171

Bending, G.D., Tumer, M.K., Rayns, F., Marx, M.C., and wood, M. (2004) Microbial and biochemical soil quality indicators and their potential for differentiating areas under contrasting agricultural management regimes. Soil Biol Biochem. 36: 1785 - 1792.

Black, C.A. (Ed.) (1965) Methods of Soil Analysis. Parts 1 and 2. Am. Soc. Agron., Madison, Wisconsin. USA.

Brookes, P.C. Landman, A., Pruden, G. and Jenkinson, D.S. (1985) Chloroform fumigation and the release of soil nitrogen: a rapid direct extraction method to measure microbial biomass nitrogen in soil. Soil Biol. Biochem. 17: $837-842$.

Chen, C., Payne, W.A., Smiley, R.W. and Stoltz, M. (2003) yield and water use efficiency of eight wheat cultivars planted on seven dates in northeastern Oregon. Agron. J. 95: $836-843$.

Crecchio C., Curci, M., Mininni, R., Ricciuti, P., and Ruggiero, P. (2001) Short term effects of municipal solid waste compost amendments on soil carbon and nitrogen content, some enzyme activities and genetic diversity. Biol. Fert. Soils. 34: $311-318$.

Feng, X.J. and Simpson, M.J. (2009) Temperature and substrate controls on microbial phospholipids fatty acid composition during incubation of grassland soils contrasting in organic matter quality. Soil Biol. Biochem. 41: $804-812$.
Ge, G., Li, Z., Fan, F., Chu, G., Hou, Z and Liang, Y. (2010) Soil biological activity and their seasonal variations in response to long-term application of organic and inorganic fertilizers. Plant Soil. 326: 31 - 44.

Jackson, M.L. (1973) Soil Chemical Analysis, Prentice Hall, Inc. Englewood Cliffs, N.J.

Kaloosh, A.A. (1978) Factors affecting carbon evolution from soils of the northwestern Mediterranean coast. M. Sc. Thesis., Faculty of Agriculture, Alexandria University, Egypt.

Kaur, K., Kapoor, K.K. and Gupta, A.P. (2005) Impact of organic manures with and without mineral fertilizers on soil chemical and biological properties under tropical conditions. J. Plant Nutr. Soil Sci. 168: 117 - 122.

Laegreid, M., Bockman, O.C. and Kaarstad, O. (1999) Agriculture, fertilizer and the environment. CAB1 Publishing. Norsk Hydro ASA. Olso, Norway.

Liang, Y.C., Yang, Y.F., Yang C.G., Shen, Q.R., Zhou, J.M. and Yang, L.Z. (2003) Soil enzymatic activity and growth of rice and barley as influenced by organic manure in an anthropogenic soil. Geoderma. 115: 149 - 160.

Lovell, R.D. and Hatch, D.J. (1998) Stimulation of microbial activity following spring application of nitrogen. Bio. Fert. Soils. 26: $28-30$

Matson, P.A., Naylor, R. and Monasterio, O. (1998) Integrated of environmental, agronomic, and economic aspects of fertilizer management. Sci. 280: 112 - 115.

Murphy, D.V., Stockdale, E.A., Poulton, P.R., Willison, T. W., and Goulding, K.W.T. (2007) Seasonal dynamics of carbon and nitrogen pools and fluxes under continuous arable and leyarable rotations in a temperate environment. Eur. J. Soil. Sci. 58: 1410 - 1424

Page, A.L., Miller, R.H., and Keeny, D.R. (1982) Methods of Soil Analysis. Part 2: Chemical and Microbiological Properties. Am. Soc. Agron., Madison, Wisconsin, USA.

Ros, M., Hernandez, M.T. and Garcia, C. (2003) Soil microbial activity after restoration of a semiarid soil by organic amendments. Soil Biol Biochem. 33: 463 - 469

Russell, R.S. (1977) Plant root systems: Their function and interaction with the soil. McGrow-Hill Book company (UK) Limited, London.

Ryan, J. Masri, S., Habib. H., Garabet, S. and Diekmann, J. (1997) Soils of ICARDA's Agricultural Stations and Sites: Climate, Classification, Physical and Chemical Properties and Land Use. ICARDA, Aleppo, Syria.

Stell, R.G., and Torrie, T.H. (1984) Principals and Procedures of Statistics. McGrow Hill, New York, USA.

Voroney, R.P. and Paul, E.A. (1984) Determination of KC and $\mathrm{KN}$ in situ for calibration of chloroform - fumigation - incubation method. Soil Biol. Biochem.

16: $9-14$ 


\section{الملخص العربي}

\section{تقييم تأثير التسميد النيتروجينى والتسميد الحيوى وإضافى سماد المزرعة على الكتلة الحيوية الميكروبية والتنفس لأرض جيرية}

إبراهيم حسين السكرى، أحمد إسماعيل عبد العال، حسين الظاهر جمعة

(متوسط القيم 413,7 و 675,3 ملجـرام كربون/ كيلوجرام

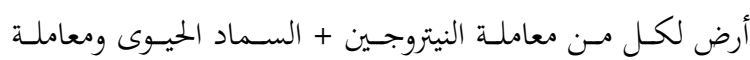
النيتروجين+ سماد المزرعة على التوالى) عن تلك التى جمعت عند مراحل التفريغ والحصاد.

كانست مسـتويات الكتلـة الحيويـة الميكروبيـة للنيتروجـين أكسبر في

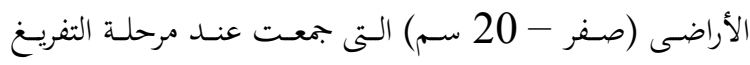
(متوسط القيم 225,3 و 352,1 مليجرام نيتروجين/ كيلوجرام أرض لكـل مـن معاملـة النيتروجـين + السـماد الحيـوى ومعاملـة النيتروجين + سماد المزرعة على التوالى) عن تلك التى جمعت عند التئد مراحل طرد السنابل والحصاد. كانست مستويات تـنفس الأرض أكسبر في الأراضسى (صفر - 20



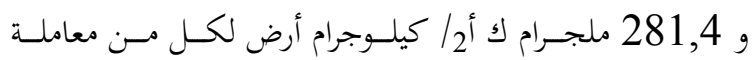

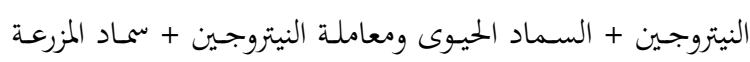
على التوالى) عن تلك التى جمعت عند مراحل التفريغ والحصاد. ونستتنج مـن هذه الدراسة أن إضافة السماد العضوى مثل سمـاد

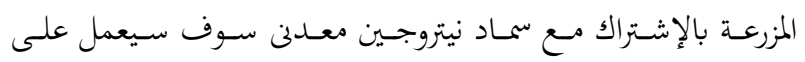
إستمرارية حفظ وجود مستويات مرتفعة من الكتلة الحيوية الميكروبية

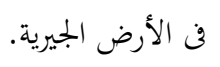

تمدف الدراسة الحالية تقييم تأثير إضـافة سمـاد النيتروجين المعددنى منفرداً أو بالإضافة المشتركة مع أى من السماد الحيوى أو سماد المزرعة
على كل من الكتلة الحيوية الميكروبية للكربون، الكتلة الحيوية الميكروبية للنيتروجين وتنفس الأرض في عينات أراضى جمعت عند مراحل النمو :

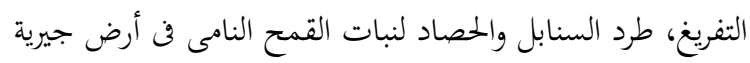
أجريست بتربـة حقليـة في محطـة بحسوث النبوباريـة (وزارة الزراعـة



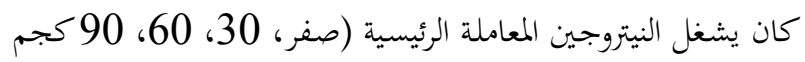

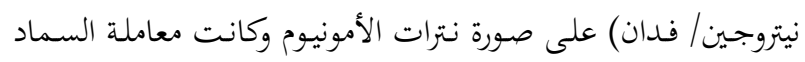

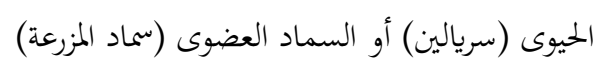

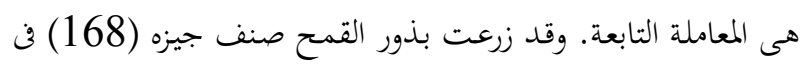

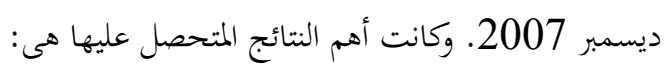
وججود زيادة معنوية لكل من الكتلة الحيوية الميكروبية للكربون والكتلة

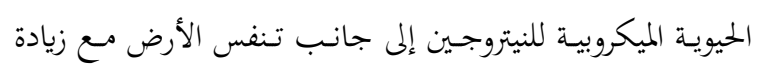


الحيوى أو سماد المزرعة.

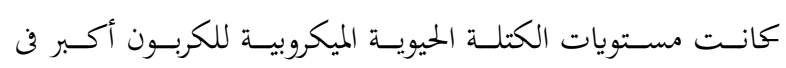
الأراضى(صفر - 20سم) التى جمعت عند مرحلة طرد السنابل 